The Christians Who Became Jews 
S Y N K R I S I S

Comparative Approaches to Early Christianity in Greco-Roman Culture

\section{S E R I E S E D I T O R S}

Dale B. Martin (Yale University) and L. L. Welborn (Fordham University)

Synkrisis is a project that invites scholars of early Christianity and the Greco-Roman world to collaborate toward the goal of rigorous comparison. Each volume in the series provides immersion in an aspect of Greco-Roman culture, so as to make possible a comparison of the controlling logics that emerge from the discourses of Greco-Roman and early Christian writers. In contrast to older "history of religions" approaches, which looked for similarities between religions in order to posit relations of influence and dependency, Synkrisis embraces a fuller conception of the complexities of culture, viewing Greco-Roman religions and early Christianity as members of a comparative class. The differential comparisons promoted by Synkrisis may serve to refine and correct the theoretical and historical models employed by scholars who seek to understand and interpret the Greco-Roman world. With its allusion to the rhetorical exercises of the Greco-Roman world, the series title recognizes that the comparative enterprise is a construction of the scholar's mind and serves the scholar's theoretical interests.

\section{E D I T O R I A L B O A R D}

Loveday Alexander (Sheffield University)

John Bodel (Brown University)

Kimberly Bowes (University of Pennsylvania)

Daniel Boyarin (University of California, Berkeley)

Fritz Graf (Ohio State University)

Ronald F. Hock (University of Southern California)

Hans-Josef Klauck (University of Chicago)

Angela Standhartinger (Marburg University)

Stanley K. Stowers (Brown University) 


\title{
The Christians
}

\section{Who Became Jews}

\section{Acts of the Apostles and}

Ethnicity in the Roman City

\section{Christopher Stroup}

\author{
Yale \\ UNIVERSITY PRESS \\ New Haven \& London
}


Published with assistance from the foundation established in memory of Amasa Stone Mather of the Class of 1907, Yale College.

Copyright (C) 2020 by Yale University.

All rights reserved.

This book may not be reproduced, in whole or in part, including illustrations, in any form (beyond that copying permitted by Sections 107 and 108 of the U.S. Copyright Law and except by reviewers for the public press), without written permission from the publishers.

Yale University Press books may be purchased in quantity for educational, business, or promotional use. For information, please e-mail sales.press@yale.edu (U.S. office) or sales@yaleup.co.uk (U.K. office).

Set in Monotype Bulmer type by Westchester Publishing Services.

Printed in the United States of America.

Library of Congress Control Number: 2019947773

ISBN 978-0-300-24789-3 (hardcover : alk. paper)

A catalogue record for this book is available from the British Library.

This paper meets the requirements of ANSI/NISO Z39.48-1992 (Permanence of Paper).

$\begin{array}{llllllllll}10 & 9 & 8 & 7 & 6 & 5 & 4 & 3 & 2 & 1\end{array}$ 
For Amy 
This page intentionally left blank 